FATIMA JINNAH

Women University, Rawalpindi, Pakistan

DR SHAHZADI PAKEEZA

Incharge, Department of Islamic Studies

\title{
Gender and Islam: Normative Approach in Islamic Law
}

\begin{abstract}
The normative regulations in Islamic Law and the diverse cultural practices among Muslims are not consistent with each other. Muslims' perceptions and response to these customary traditions must be evaluated on the normative standards of Islam that are mislaid. For this purpose a shift to a mode of understanding and bringing about transcultural exchange of ideas may be incorporated in contrast to the prevailing hypercritical dominative standards. With this an understanding may be developed to concentrate the needs and practices of gender in Islamic perspective. Thus general gender practices may be assessed to see their compliance with normative standards of Islam.
\end{abstract}

\section{Introduction}

The issues emerging out of genderrelated subject matter are as old as human civilization. The present debate on gender issues and the concern of academic world on gender studies is comparatively modern prerogative. An analogous curiosity is to learn about the gender relations in Muslim societies which seem part of complex relations between Islam and the West. The discussions on gender and Islam is not completely absorbing the over-whelming global changes due to modernity, as changing global context brings in more challenges to social and cultural unpredictable circles. While talking about the gender issues, a clear distinction must be made between normative teachings of Islam that may be variant or inconsistent with diverse cultural practices in Muslim societies. Thus, to evaluate the practices prevalent in Muslim societies, normative teachings of Islam can be set as the criteria to evaluate their compliance with Islam.

\section{Gender in Muslim Society}

A critical analysis to understand the gender issues in Muslim societies, a dominant judgmental and manipulative mode must be replaced with changing perceptions and attitudes to an approach of understanding the cultural pragmatism in absorbing trans-cultural interaction and enlightenment. This will help in drafting a framework to meet the requirements on a realistic level understanding gender relations in an Islamic context. 
The harmonization of both genders is the main key to synchronization and happiness, depending upon the balance in carrying out the nature and functions of each gender in the relative (or relational) sense. The world is dissected into manly and womanly bifurcation that cannot be merged without realization of harmony between the both. Islam gives a possible solution to achieve this goal by making both sexes available to each other with a sense of respect and radiance.

\section{Influences of Social Development on Gender Relations}

Traditions, values, belief systems and values reflect in social approaches on one hand while economic and technological factors play a vital role in social organization and cultural attitudes. Muslim scholars assess that such gender relation can be traced to social development keeping in view many determining factors including discipline of the researcher, traditions, sources, personal and ideological basis. Generally Muslim societies demonstrate a cultural identity, accredited to prevalence and distinctive homogenizing influence of Islam on structure and development in different societies. This cultural specificity is substantiation of the fact that Islam as a religion lays great emphasis on faith as well as community that is reflected as historical and sociological reality in Muslim communities. Thus the linkage between Islam and community association is more than hypothetical notion in Muslim society. Another dominant factor in the same context is family that always has been a primary social unit in Islam having the basis of gender relation and sex role differentiation; as gender is the most important feature for its conception and development. Gender as a social construct thus lies at the convergence of culture and biology.

\section{Islam on Gender Roles}

There are a number of verses in the Qur'an that lay down its essential teaching on gender and genderization. A few of these lay down the equality of the male and female sexes and/or genders, but the more decisive verses lay down the hierarchy of the sexes and/or genders. Whether the Qur'an is contradictory or, at least, inconsistent, will depend upon how one reads the verses in question, but, it seems safe to maintain, that while, on the one hand, the Qur'an appears to put both male and female Muslims on a plane of spiritual equality, it, on the other hand, certainly seems to put them on a footing of social, economic, psychological, and cultural inequality. In these respects, it favors what can only be described as patriarchy and sexual hierarchy, with superiority of the male over the female. In the present research both sets of a few selected verses of each kind in the Qur'an, viz., those that favor the equality of man and woman and those that favor the inequality of man and woman are analyzed. Among the verses that favor male-female equality may be included also those that emphasize the mutuality and/or complementing the two. 


\section{Quranic arguments for Legal Equality and Inequality}

There are two kinds of reasoning presented in the Holy Quran and traditions about rights of women. One kind of verses regards both men and women having same rights with no difference in law perspective. The other kind claims men are superior to women but with certain responsibilities of support and protection of women.

\section{Verses that Imply Equality}

The verses that imply equality of men and women fall into five categories of equality in creation, hereafter, rights and duties, rewards and punishments and in married life. Both men and women are charged with certain responsibilities and duties that enjoin on them certain obligations as mentioned in the Holy Quran 9:71. On the basis of performance of these rights and duties, similar rewards and punishments are specified without any discrimination of gender in 48:5-6; 57:12-13; 5:38 and 24: 2, 26 \& 31 equally for both of them. Equality in married life is emphasized in the Holy Quran 30:21; 2:187 explaining that both are source of comfort for each other thus peace and tranquility should be the basis of their relation (in marital life).

\section{Verses that Imply Inequality}

The evidences quoted from the Holy Quran and Sunnah in this context are chiefly four verses and two traditions. Verse 228 of Surah Baqarah denote that men have a degree above women; while Verse 34 of Surah Nisa mention that men are superior over women as they support them from their means. A tradition of the Holy Prophet (S.A.W) is quoted from SahihBukhari that the Holy Prophet said that people who entrust their affairs to women will never find prosperity and salvation. A tradition from Hadrat Ali (R.A) is also presented in the same context in which he said women are inferior to men $\mathrm{n}$ faith, wealth and reason.

\section{Arguments Balancing the Equality}

The arguments given in female witness being half of man (al Baqarah 2:282) is voided by Quranic Verses 6-9 of Surah al Noor that equates the testimony of both genders as equal. The reference of half witness of woman is only in case of financial transactions that were not to assert any superiority of gender rather to prevent any error or confusion in financial transactions. Similarly, the use of word Qiwamah for rendering the gender inequality is not apt, as it deals with role differentiation, financial responsibilities of men and complementing the roles of husband and wife, which is no way can be an argument of gender discrimination or superiority of one sex on another. The words of the Holy Prophet (S.A.W), and his companion, Ali (R.A) are interpreted by many exegeses' as specific and not generalized. Thus the hadith is not conclusive evidence of categorical exclusion. 


\section{Cultural specificity of Muslim settings}

Muslim societies have specified the gender roles in social, cultural and religious circles for both men and women to differentiate between 'masculine' or 'feminine' (gender). The communal and cultural patterns learned in a particular context, supported by education and economics; often adversely affect women socio-economic status and freedom and right due to gender-bias. In the Holy Quran, numerous verses declare women to be equal to men in human dignity, social and spiritual rights and ethical equality in making independent decisions in family matters. The present era emphasize on a universally binding morality on one hand and a contextual relative morality on the other. The epistemological limits to human knowledge have been unsuccessful to generate a stable framework that may relate relative to absolute and change to constancy. It is not easy to understand gender in Islamic societies with fixed and inflexible notions for gender. Since social relations and community are an entirety and gender relations are one aspect of social relations; thus a social whole must not be abstracted or understood reductively Gender issues must be addressed with a multi- dimensional approach as every given society has developed a certain status about gender subject to multiple influences. Creation is a demonstration of division in diverse range in primeval schism of two challenging principles manifested in this world of human life as the male and female sexes. The division as two-fold by segregation of the microcosm into man and woman is a most profound feature of human nature. For this reason Allah Almighty speaks of creating mankind in different pairs and the distinction between the two sexes shows His Wisdom and Providence. The distinction is essential to the meaning of the human state (identified with the Universal or Perfect Man-alinsnal-kmil) which both men and women carry within the depths of their being. Despite the fact that gender is a fundamental category in any social order, its relative importance is conditional on the organization and cultural preferences and discernment in that society. Muslim societies have predominantly effective significant elements in the form of religion and family. The social paradigm for understanding and resolving gender issue in a society can be conceptualized from the Quranic notions relevant to societal conceptions. The Holy Quran asserts that any theory or hypothesis must be put into reality and practice and have a facet of putting information into context. The examples from the life of the Holy Prophet (S.A.W) and early centuries of Islam form an imperative factor in constituting the paradigm of gender and gender relations in the Muslim experience. However the development, or change within a system or process regarding social reforms is yet an unachievable target as the same approach and rationale is prevailing in Muslim societies that needed to be abstracted. Hence, the social behaviors and cultural development criterion need extensive scrutiny in order to acclimatize the practice and actuality of gender relations and gender related debate in Muslim societies. 


\section{Conclusion}

A co mmon perception about Muslim societies is that Islam has supremacy and a dominating impact on the structure and development of these societies, thus having a cultural specificity. This notion of intersection between Islam and society correlation is not mere abstraction rather a factual veracity. Islam holds both men and women in equal esteem and emphasizes their equal worth before Allah, but recognizes that they are physically and emotionally different and play different parts in society. The Islamic concept of gender relations can be described as complementary rather than competitive.

\title{
UtRe ty hULUUC.

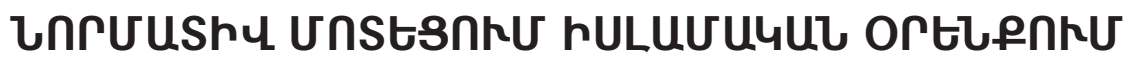

\author{
SUคhUU shしu

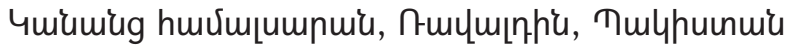 \\ ?ก४Sกก ₹U<RUาh TU4hRU

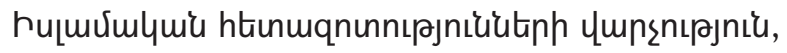

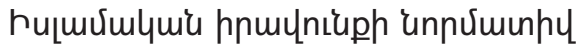

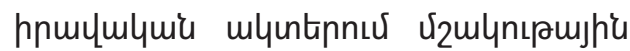

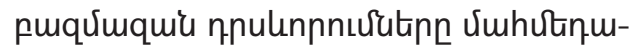

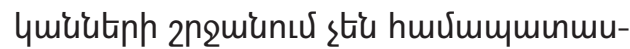
fumiunsu upujoing: Unıunцúuiuititph

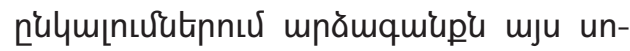

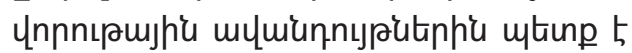

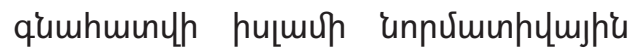
zumumuh2utinny, nnnup futnupjnın-

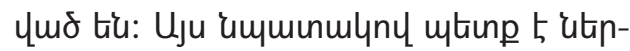

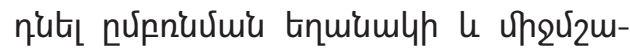
ynıрujhe qunumumpitinh snnfumiaml-

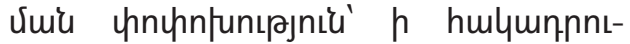
pjniu qtiph2funn qtippaumnuunulymir qtinuly2hn smumiuhzititiph: Ujumpund'

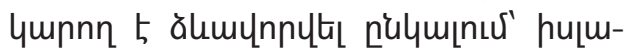

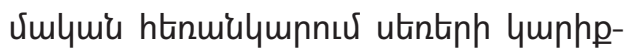

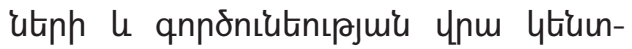

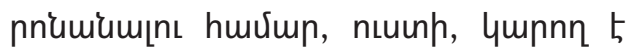

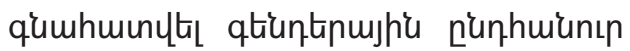
unnăn' untưutąnı, pt nnpuiuny tú hu-

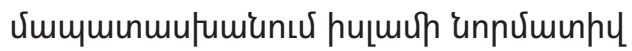
surumunzutinhis: 


\section{ПОЛ И ИСЛАМ. НОРМАТИВНЫЙ ПОДХОД К ИСЛАМСКОМУ ПРАВУ}

\section{ФАТИМА ДЖИННА}

Женский университет

Равалдин, Пакистан

\section{ДОКТОР ШАХЗАДИ ПАКИЗА}

Департамент исламских исследований,

Исламские правовые нормативные акты и разнообразные культурные проявления не соответствуют друг другу в мусульманской среде. Мусульманские представления и восприятие привычных традиций следует оценивать по нормативам ислама. С этой целью необходимо внести изменения в режим понимания и межкультурный обмен идеями в противовес преобладающим сверхкритичным критериям. Таким образом, можно сорормировать восприятие для сосредоточения на потребностях и деятельности полов в исламской перспективе. Итак, общий гендерный опыт должен быть проанализирован для определения оценки соответствия нормативным критериям ислама. 